ISSN No. 0974-035X

An indexed refereed \& peer-reviewed journal of higher education

Towards Excellence

UGC-HUMAN RESOURCE DEVELOPMENT CENTRE

Gujarat University, Ahmedabad-380009, Gujarat, India

\title{
DARUL AMAN GROUNDWATER QUALITY ASSESSMENT OF AFGHANISTAN
}

\author{
Abdul Mohammad Aziz \\ Mohammad Dawod Shirzad \\ Prof. Dr. Hitesh A. Solanki
}

Abstract

Groundwater is the most important natural resource used for drinking by many people around the world, especially in arid and semi-arid areas. Groundwater is the major source of drinking water in rural as well as in urban areas and over $94 \%$ of the drinking water demand is met by groundwater. The study was carried out to assess the ground water quality and its suitability for drinking purpose in Darulaman, Kabul Afghanistan. For this purpose, four water samples collected from bore wells of villages of study area were analyzed for different chemical parameters such as $\mathrm{pH}$,total, magnesium hardness, sodium, chloride, nitrate, fluoride, cyanide. The results of analysis carried out showed the following concentration ranges: $\mathrm{pH}$ value in this research found from (7.423 to 7.45 , calcium hardness from (96.19 to 192.3$) \mathrm{mg} / \mathrm{L}$. Magnesium hardness varied from (40.2 to 90.14$) \mathrm{mg} / \mathrm{L}$ and chloride from (0.02 to 17$) \mathrm{mg} / \mathrm{L}$. Values of nitrate concentration varied from (0.5 to 3.5$) \mathrm{mg} / \mathrm{L}$ and fluoride from $(0.22$ to 0.41$) \mathrm{mg} / \mathrm{L}$., cyanide from ranges $(0.002$ to 0.007 . The study reveals that almost all parameters were exceeding the permissible limits. As per the desirable and maximum permissible limit for fluoride, nitrate, total dissolved solids and chloride in drinking water, determined by WHO standards, groundwater sources are unfit for drinking purposes respectively. After evaluating the data of this study, it is concluded that drinking water of Darul Aman is not potable and there is an instant need to take ameliorative steps in this region to prevent the population from adverse health effects.

Key Words: Ground water, water quality, water quality index, Water quality parameters, Kabul city, waterborne diseases. 


\section{Introduction}

Water is most vital liquid for maintaining the life on the earth. Kabul has experienced quick and uncontrolled population growth in significance of owing high population growth in Afghanistan with deficiency of drinking water [11]. A feasibility study for the extension of the Kabul water supply system, conducted in 2004, shows an estimated population in 2015 of 4,089,000, with water demand about 123.4 million m3/year [12]. Though, the projected groundwater accessibility in Kabul city, being approximately 44 million m3/year, can only supply around 2 million populations at a modest per capita depletion of 50 lit/day [14]. Besides the insufficient water resource, Kabul is one of the least developed cities of the world regarding access to clean water supplies and effective sanitation [13].

In 2015, all United Nations Member States adopted the Sustainable Development Goals (SDGs) as a worldwide call to action to end deficiency, protect the planet and ensure that all people enjoy peace and prosperity by 2030 . SDG 6 "Equitable access to safe and affordable water for all" calls, among others, for important developments to be made in drinking water quality. As a cross-cutting goal, progress in SDG6 will have important spillover benefits for other goals such as improving public health, reducing poverty and hunger, improving other linked environmental systems, and vice versa. Therefore, all development activities within SDG 6 must take into account broader social, economic, and environmental objectives of achieving overall sustainability in a society [15].

According to the World Health Organization (WHO) Fact sheet from 2015, nearly 1.8 billion of the world population is faced with the use of polluted potable water sources, and 663 million people are using unsafe drinking water sources [16]. Various Asian countries, particularly in the low, and middle-income regions [17], face serious challenges related to the improvement of drinking water quality due to lower levels of overall development, large populations, high levels of migration and urbanization, poor infrastructure, as well as effects from changing environmental conditions (particularly climate change). Although the attention of governments, scholars, and the international development community is often on water quantity, the water quality of lakes, groundwater, and reservoirs is worsening and threaten the lives of millions [17]\&[18]. Same trends for the Kabul Basin in Afghanistan [19] stress that a high concentration of nitrate and fecal bacteria leads to severe groundwater pollution, partially explaining high infant mortality in the region.

The authorities in Afghanistan aim to reach SDG 6 by 2030, but unfortunately, the United Nations Children Fund (UNICEF) report in 2011 shows what an extraordinarily difficult task this is with nearly 52 percent of the population in Afghanistan without access to safe drinking water, and 63 percent deprived of standard sanitation [20]. According to the WHO Drinking-Water Quality 
Guidelines (2011, p. 1), "Safe drinking-water does not represent any significant risk to health over a lifetime of consumption, including different sensitivities that may occur between life stages." Standard sanitation includes sanitation facilities that hygienically separate human excreta from human contact [23].

Kabul does not have functioning public water treatment plants, water filtration systems, or sewage treatment plants (even the systems left from the times of the Soviet intervention are outdated and not functioning for long) [24]. In Kabul city, only 18 percent of the population has access to piped water [26]. Despite the scope and scale of poor sanitation and lack of safe drinking water in Kabul [25], there has been so far little research and scientific evidence that describes the state of the drinking water quality. This research is designed to investigate the quality of drinking water used by Kabul residents. The aim is not only to find the problems associated with water quality but also to identify the gaps and provide significant governance recommendations to the authorities. This is the area in health sanitation that has yet to be tackled on. There are minimal researches have been conducted by far. Our intention is also to document the method and approach to implement drinking water quality assessment in particularly challenging conditions that many developing countries face. There are still no or little researches that explain how one can undertake a study aiming at assessment of drinking water quality, not only in the context of Kabul Afghanistan, but also in broader Central Asian region. Probably, due to the poor states of infrastructures with mixed sources of water supply and poor sanitation.

The present study looks into District 5 of Kabul city, which is one of the most populous districts of the city. At the same time, because District 5 has a qanat - a source of drinking water perceived to be safe by the local population, the general public across the entire Kabul often comes to District 5 to collect drinking water. The estimated population of District 5 is around 150,000 [20]. Due to rapid migration linked with the war in Afghanistan and unplanned settlements in District 5, a limited number of households are linked to the open sewerage drain. In contrast, the remaining households have septic tanks and dry latrines [22]. Human waste is being disposed of in unprotected ways, causing potential surface and groundwater contamination [21]. Therefore, this district is a typical case of very challenging areas to reach the SDG 6. Thus, the present study focuses on drinking water quality in the example of District 5 of Kabul city. Physical, chemical, and bacterial parameters from four different water supply systems have been analyzed, and both technical and governance recommendations have been developed based on the findings. 


\section{Problem Statement}

Water pollution is the contamination of water bodies that occur when pollutant is indirectly or directly discharge into water bodies without adequate treatment to remove the harmful sediment. It will give an affect to ecosystem on quality of water and human life and become an issue nowadays. Besides, water resources are gradually becoming polluted and unavailable due to human or industrial activities. Increasing contamination of freshwater systems with thousands of industrial and natural chemical compounds is one of the key environmental problems facing humanity worldwide [7].

There is a need to better understand the groundwater resources and management of these resources to aid in the planning for potential times of water shortage. Given that groundwater is an invisible resource, residents tend to be unaware of groundwater problems until they happen? This dissertation provides an approach for better defining the groundwater resources available for distribution in small island environments, acquiring information on groundwater consumption, planning for the education of stakeholders in a concrete and comprehensible manner, and changing the institutional framework to streamline responsibility for groundwater management. Historically, the planning process has involved predominantly the development of policy to determine for example lot size, land use, location of septic systems, and has not been related to the available groundwater resources[8].

In addition, it also will affect human activities in their daily life such as cooking, tourism and washing and it will threaten aquatic life. This study was conducted in order to measure water quality status in Darul Aman and to classify the water quality based on Water Quality Index (WQI) that purposed by Department of Environment.

\section{Importance of research}

Water is essential to human and other forms of life. There is a lot of water; two-thirds of the world is covered by the ocean, while roughly $3.5 \%$ of the global land mass is inundated permanently with water. Water exists in the hydrosphere in a continuous cycle it is evaporated from the surface of the earth but subsequently condenses in the atmosphere and returns as liquid water. The world is not going to run out of water; there is as much as ever or is ever going to be[5].

Availability of freshwater has always been and continues to be an important factor affecting human population. But, as the world's population has grown, water quality has become an equally important issue. Professionals in many disciplines need a basic understanding of the factors controlling concentrations of water quality variables as well as the effect of water quality of aquatic life and water use by humans. These individuals also need to know how to manage the resources or activities for which they are responsible in a manner that is protective of water quality[3]. 
The surface water quality is very sensitive and critical issue in many countries and so on in our country. Also, with an increased understanding of the importance of drinking water quality to public health and raw water quality to aquatic life, there is a great need to assess surface and ground water quality [2].

Unfortunately, in developing countries the drinking water quality is continuously being contaminated and hazardous for human use due to high growth of population, expansion in industries, throwing away of waste water and chemical effluents into canals and other water sources. According to recent estimates, the quantity of available water in developing regions of South Asia, Middle East and Africa is decreasing sharply while quality of water is deteriorating rapidly due to fast urbanization, deforestation, land degradation [5].

Worldwide, more people are dying from poor quality of water per year than from all forms of violence including war and it is estimated that about $26 \%$ of all deaths are outcome from contagious diseases caused by pathogenic bacteria [9].

Lack of access to safe and clean water created waterborne diseases excessively by the residents of slums in India. Diarrhea, a waterborne disease is reported as the leading cause of death in infants and children in the country while every fifth citizen suffers from illness and disease caused by the polluted water [8].

\section{Objective of Study}

1. To analyze groundwater quality for the following parameters Chemical

2. To assess groundwater quality and its suitability for drinking purpose.

\section{Questions}

1. Does the Kabul city, Darul Aman area groundwater has the equivalent water quality parameters with National and international standards?

2. Whether this area water quality is suitable for drinking purposes?

3. What are the main pollutants of groundwater in Darul Aman?

\section{Literature review}

Water is one of the most important substances on earth. All plants and animals must have water to survive. If there was no water, there would be no life on earth. Water is not only essential to life but intimately interwoven with quality of life across the globe. Access to enough clean water is crucial every day for every person. Changes in the quality, quantity and natural cycle of water and water systems have far-reaching impacts on all aspects of human life. As the human population continues 
to grow and the global clean water supply is reduced by consumption, contamination and climate change, water issues will only increase in complexity and importance [1]\& [5].

It is important that the water which people drink and use for other purposes is clean water. This means that the water must be free of germs and chemicals and be clean. It means that we need to understand water quality in order to protect our health, and also the health of ecosystems. Those, of course, are the main reasons we are interested in water quality, so that we make sure our drinking water is safe and we are not damaging the environment. In this area lots of researchers worked and resulted as in bellow: [3] \&[4].

Veena Iyer, Nandini Choudhury, Gulrez Shah Azhar, Bhushan Somvanshi have been work on Drinking Water Quality Surveillance in a Vulnerable Urban Ward of Ahmedabad and concluded that the water sampling strategy for the city of Ahmedabad needs to include periodic surveys of water actually consumed by the community and the testing strategy needs to incorporate tests for viruses, heavy metals, fluorides and surface contaminants at appropriate intervals of time and distance in piped water, using maps of the water distribution systems. There is a need for consultations with experts to adjust the numbers and sophistication of tests to appropriately reflect available scientific knowledge about Drinking Water Quality Surveillance. Also, a practice of Sanitation Risk Scoring by Sanitary Inspectors of the city needs to be developed and implemented. Although there are official references to reducing groundwater exploitation. Guidelines need to be developed for tapping into underground aquifers in the country [10]\&[8].

SeherDirican, 2013 studied the Assessment of Water Quality Using Physiochemical.

\section{Water Quality Index Method}

Initially, WQI was developed by Horton (1965) in United States by selecting 10 most commonly used water quality variables like dissolved oxygen (DO), $\mathrm{pH}$, coliforms, specific conductance, alkalinity and chloride etc. and has been widely applied and accepted in European, African and Asian countries (Solanki, 2012). The assigned weight reflected significance of a parameter for a particular use and has considerable impact on the index. Furthermore, a new WQI similar to Horton's index has also been developed by the group of Brown in 1970, which was based on weights to individual parameter. Recently, many modifications have been considered for WQI concept through various scientists and experts[2]\&[4].

Table 1: WQI Value [6].

\begin{tabular}{|l|l|l|}
\hline WQI Value & Rating of Water Quality & Grading \\
\hline $0-25$ & Excellent water quality & A \\
\hline
\end{tabular}


Towards Excellence: An Indexed, Refereed \& Peer Reviewed Journal of Higher Education / Abdul

Mohammad Aziz, Mohammad Dawod Shirzad, Dr. Hitesh Solanki / Page 734-751

\begin{tabular}{|l|l|l|}
\hline $26-50$ & Good water quality & B \\
\hline $51-75$ & Poor water quality & C \\
\hline $76-100$ & Very Poor water quality & D \\
\hline Above 100 & Unsuitable for drinking purpose & E \\
\hline
\end{tabular}

\section{Afghanistan}

Afghanistan is a landlocked country in Asia. Afghanistan is bordered by Pakistan to the east and south; Iran to the west; Turkmenistan, Uzbekistan, and Tajikistan to the north; and in the far northeast, China. Occupying 652,000 square kilometers $(252,000$ sq. mi), it is a mountainous country with plains in the north and southwest. Kabul is the capital and largest city. The population is 32 million [3]\&[4].

In $2015,55 \%$ of the population had access to "improved" water, $78 \%$ and $47 \%$, in urban and rural areas, respectively. Still, in that year, 14 million people were without access to "improved" water. Access to an improved water source does not mean that the water is safe to drink. For example, protected shallow wells in urban areas are often contaminated with bacteria. Piped water supply can also be contaminated. Households without access to an improved source take water from streams and rivers, open wells and unprotected springs, all of which are also often polluted. In rural areas women and girls walk long distances to fetch water [6] \&[4].

Water is the main source of energy production and economy in Afghanistan where agriculture accounts for more than $50 \%$ of the country's gross domestic product (GDP). Access to safe drinking water is still a problem in the country, which has caused different health issues and even child mortality especially in rural areas. Groundwater is the main source of drinking water in the country. However, little knowledge is available about the quality of groundwater throughout the entire country, and its quality has not been investigated extensively yet like in other countries in the world. While most people think that consuming groundwater is a reliable and safe source of drinking water for health, the United Nations (UN) agencies report various kinds of waterborne diseases and even child mortalities due to drinking water quality in the country. In this article, significant orogenic and anthropogenic factors that play a vital role in groundwater contamination of the country are identified and explained. Different gynogenic contaminations such as arsenic, fluoride, sulfate, and boron occur in several areas of Afghanistan that have a direct effect on human health. The water quality mapping for Afghanistan is completed for half of the country, which shows that groundwater is plagued by 
Towards Excellence: An Indexed, Refereed \& Peer Reviewed Journal of Higher Education / Abdul

Mohammad Aziz, Mohammad Dawod Shirzad, Dr. Hitesh Solanki / Page 734-751

high levels of fluoride and arsenic in some areas. The water quality mapping of the other half of the country cannot be completed due to security concerns currently. Also, there are different kinds of waterborne diseases such as diarrhea, cholera, and dysentery that can be seen in different parts of the country because of anthropogenic activities which continuously deteriorate groundwater [9].

\section{Result and discussions}

\section{Discussions}

The mean value of the monitoring period for each measured groundwater quality parameter used in this study at each sampling location is presented in table 2 .

Table 2: Parameters

\begin{tabular}{|c|c|c|c|c|c|}
\hline NO & Parameters & $\begin{array}{l}\text { Sample } \\
\text { NO }\end{array}$ & Location & Value & Units \\
\hline & & S 4 & Abas Qoli Salman Fars masque & 1005 & $\mu \mathrm{s} / \mathrm{cm}$ \\
\hline \multirow{4}{*}{1} & \multirow{4}{*}{$\mathrm{pH}$} & S 1 & Elm O Farhang & 7.428 & - \\
\hline & & $\mathrm{S} 2$ & Alawdin Fatima Zahra Masque & 7.423 & - \\
\hline & & S 3 & Animal Clinic & 7.45 & - \\
\hline & & S 4 & Abas Qoli Salman Fars masque & 7.27 & - \\
\hline \multirow{4}{*}{2} & \multirow{4}{*}{ Magnesium } & S 1 & Elm O Farhang & 70.65 & $\mathrm{mg} / \mathrm{L}$ \\
\hline & & S 2 & Alawdin Fatima Zahra Masque & 90.14 & $\mathrm{mg} / \mathrm{L}$ \\
\hline & & S 3 & Animal Clinic & 75.7 & $\mathrm{mg} / \mathrm{L}$ \\
\hline & & S 4 & Abas Qoli Salman Fars masque & 40.2 & $\mathrm{mg} / \mathrm{L}$ \\
\hline \multirow{5}{*}{3} & \multirow{5}{*}{ Sodium } & $\mathrm{S} 1$ & Elm O Farhang & 84 & $\mathrm{mg} / \mathrm{L}$ \\
\hline & & $\mathrm{S} 2$ & Alawdin Fatima Zahra Masque & 230 & $\mathrm{mg} / \mathrm{L}$ \\
\hline & & S 3 & Animal Clinic & 270 & $\mathrm{mg} / \mathrm{L}$ \\
\hline & & S 4 & Abas Qoli Salman Fars masque & 250 & $\mathrm{mg} / \mathrm{L}$ \\
\hline & & S 4 & Abas Qoli Salman Fars masque & 325 & $\mathrm{mg} / \mathrm{L}$ \\
\hline \multirow{4}{*}{4} & \multirow{4}{*}{ Chloride } & S 1 & Elm O Farhang & 0.41 & $\mathrm{mg} / \mathrm{L}$ \\
\hline & & $\mathrm{S} 2$ & Alawdin Fatima Zahra Masque & 0.23 & $\mathrm{mg} / \mathrm{L}$ \\
\hline & & S 3 & Animal Clinic & 0.31 & $\mathrm{mg} / \mathrm{L}$ \\
\hline & & S 4 & Abas Qoli Salman Fars masque & 0.22 & $\mathrm{mg} / \mathrm{L}$ \\
\hline \multirow{4}{*}{5} & \multirow{4}{*}{ Fluoride } & S 1 & Elm O Farhang & 0.41 & $\mathrm{mg} / \mathrm{L}$ \\
\hline & & S 2 & Alawdin Fatima Zahra Masque & 0.23 & $\mathrm{mg} / \mathrm{L}$ \\
\hline & & S 3 & Animal Clinic & 0.31 & $\mathrm{mg} / \mathrm{L}$ \\
\hline & & S 4 & Abas Qoli Salman Fars masque & 0.22 & $\mathrm{mg} / \mathrm{L}$ \\
\hline \multirow[t]{4}{*}{6} & \multirow{4}{*}{ Phosphate } & S 1 & Elm O Farhang & 0.21 & $\mathrm{mg} / \mathrm{L}$ \\
\hline & & S 2 & Alawdin Fatima Zahra Masque & 0.08 & $\mathrm{mg} / \mathrm{L}$ \\
\hline & & S 3 & Animal Clinic & 0.11 & $\mathrm{mg} / \mathrm{L}$ \\
\hline & & S 4 & Abas Qoli Salman Fars masque & 0.11 & $\mathrm{mg} / \mathrm{L}$ \\
\hline \multirow{5}{*}{7} & \multirow{5}{*}{ Nitrate } & S 1 & Elm O Farhang & 3.5 & $\mathrm{mg} / \mathrm{L}$ \\
\hline & & $\mathrm{S} 2$ & Alawdin Fatima Zahra Masque & 0.5 & $\mathrm{mg} / \mathrm{L}$ \\
\hline & & S 3 & Animal Clinic & 2.3 & $\mathrm{mg} / \mathrm{L}$ \\
\hline & & S 4 & Abas Qoli Salman Fars masque & 1.4 & $\mathrm{mg} / \mathrm{L}$ \\
\hline & & S 1 & Elm O Farhang & 0.005 & $\mathrm{mg} / \mathrm{L}$ \\
\hline
\end{tabular}


Towards Excellence: An Indexed, Refereed \& Peer Reviewed Journal of Higher Education / Abdul

Mohammad Aziz, Mohammad Dawod Shirzad, Dr. Hitesh Solanki / Page 734-751

\begin{tabular}{|l|l|l|l|l|l|}
\hline 8 & Cyanide & S 2 & Alawdin Fatima Zahra Masque & 0.007 & $\mathrm{mg} / \mathrm{L}$ \\
\cline { 3 - 6 } & S 3 & Animal Clinic & 0.002 & $\mathrm{mg} / \mathrm{L}$ \\
\cline { 3 - 6 } & S 4 & Abas Qoli Salman Fars masque & 0.005 & $\mathrm{mg} / \mathrm{L}$ \\
\hline
\end{tabular}

\section{1- PH}

The amount of $\mathrm{pH}$ which recorded from groundwater of Darul Aman ranged from 7.27 to 7.45 with average of 7.39. The maximum $\mathrm{pH}$ value which recorded is 7.45 at Sample 3 from Animal Clinic and minimum $\mathrm{pH}$ value which recorded is 7.27 at Sample 4 from Abas Qoli Salman Fars masque. Other $\mathrm{pH}$ value which recorded from groundwater of Darul Aman is 7.428 at Sample 1 from Elm o Farhang another is 7.423 at sample 2 from Alawdin Fatima Zahra Masque. The average amount of $\mathrm{pH}$ recommended by WHO is 7.5 and recommended value by AFG National standard for temperature is also 7.5 .

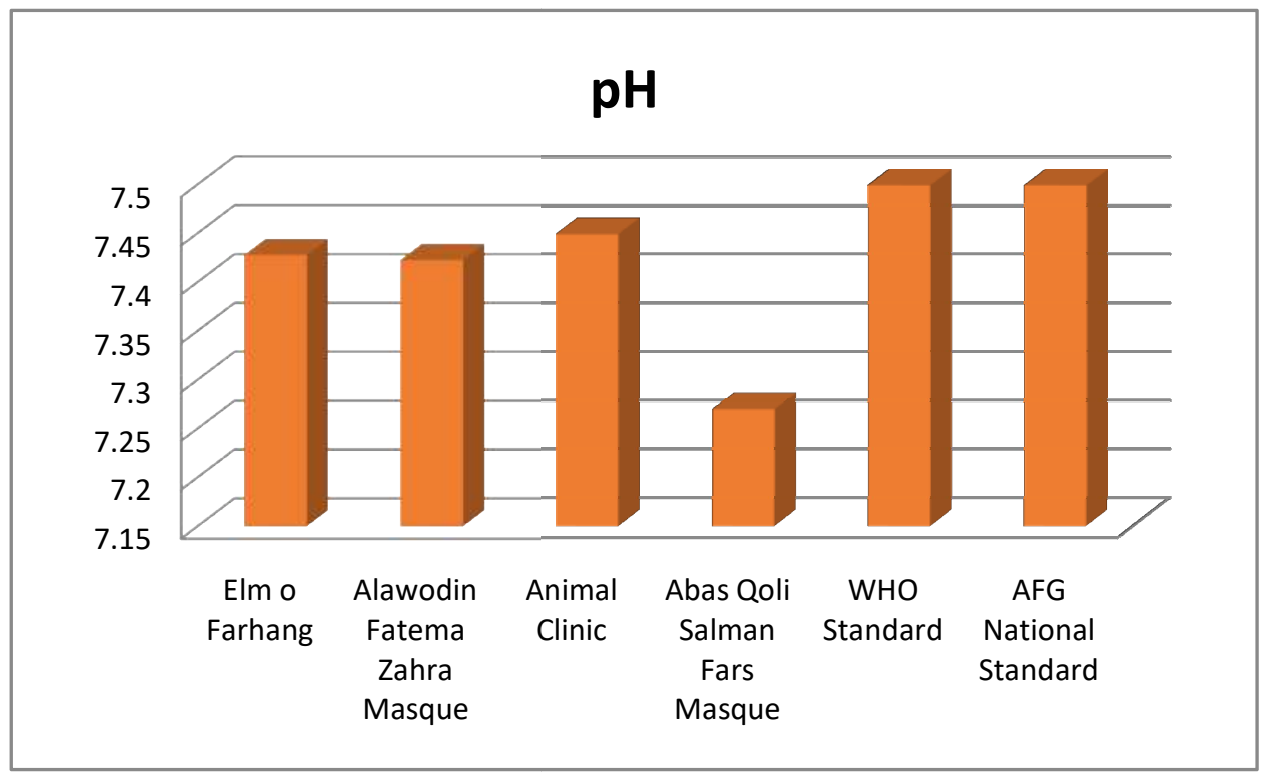

Figure 1: pH Compare

\section{2- Magnesium}

The amount of magnesium which recorded from groundwater of Darul Aman ranged from 40.2mg/L to $90.14 \mathrm{mg} / \mathrm{L}$ with average of $69.17 \mathrm{mg} / \mathrm{L}$. The maximum magnesium value which recorded is 90.14mg/L at Sample 2 from Alawdin Fatima Zahra Masque and minimum magnesium value which recorded is $40.2 \mathrm{mg} / \mathrm{L}$ at Sample 4 from Abas Qoli Salman Fars masque. Other magnesium value which recorded from groundwater of Darul Aman is $70.65 \mathrm{mg} / \mathrm{L}$ at Sample 1 from Elm o Farhang another is $75.7 \mathrm{mg} / \mathrm{L}$ at sample 3 from Animal Clinic. The amount of magnesium recommended by WHO and AFG National standard is $30 \mathrm{mg} / \mathrm{L}$. 


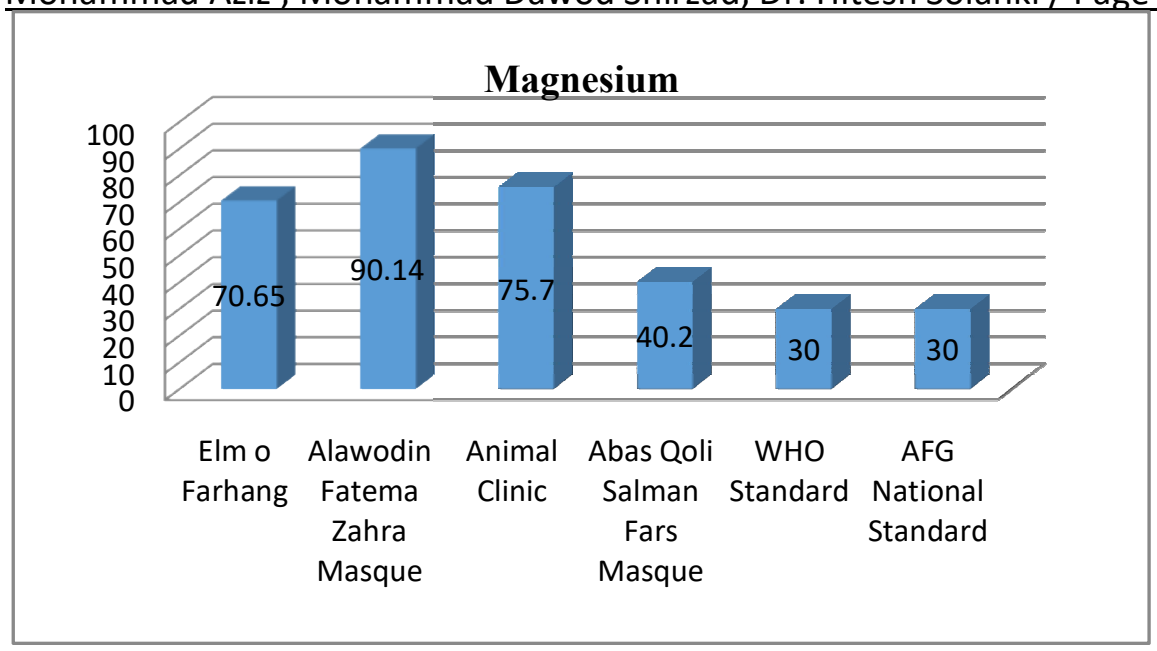

Figure 2: Magnesium Compare

\section{3- Sodium}

The amount of sodium which recorded from groundwater of Darul Aman ranged from $84 \mathrm{mg} / \mathrm{L}$ to $270 \mathrm{mg} / \mathrm{L}$ with average of $208.5 \mathrm{mg} / \mathrm{L}$. The maximum sodium value which recorded is $270 \mathrm{mg} / \mathrm{L}$ at Sample 3 from Animal Clinic and minimum sodium value which recorded is $84 \mathrm{mg} / \mathrm{L}$ at Sample 1 from Elm o Farhang. Other sodium value which recorded from groundwater of Darul Aman is 230 $\mathrm{mg} / \mathrm{L}$ at Sample 2 from Alawdin Fatima Zahra Masque another is $250 \mathrm{mg} / \mathrm{L}$ at sample 4 from Alawdin Fatima Zahra Masque. The amount of sodium recommended by WHO and AFG National standard for sodium is $200 \mathrm{mg} / \mathrm{L}$.

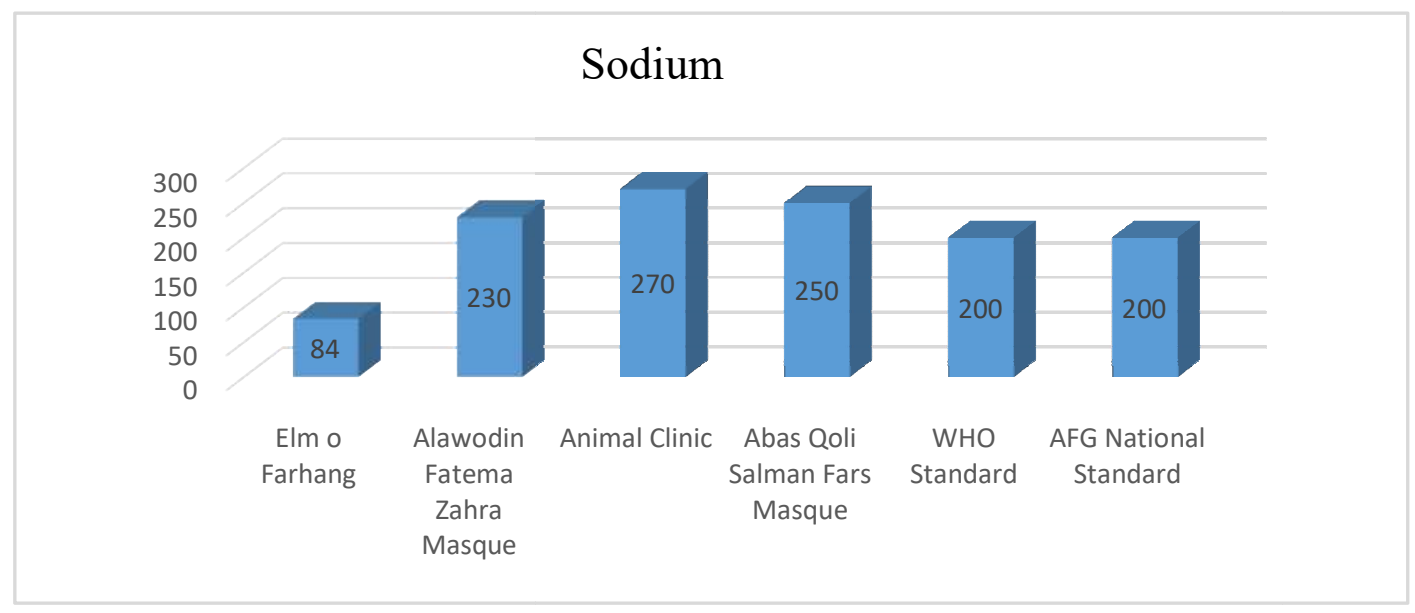

Figure 3:Sodium Compare

\section{4- Chloride}

The amount of chloride which recorded from groundwater of Darul Aman ranged from $0.02 \mathrm{mg} / \mathrm{L}$ to $17 \mathrm{mg} / \mathrm{L}$ with average of $4.59 \mathrm{mg} / \mathrm{L}$. The maximum chloride value which recorded is $17 \mathrm{mg} / \mathrm{L}$ at Sample 1 from Elm o Farhang and minimum Chloride value which recorded is $0.02 \mathrm{mg} / \mathrm{L}$ at Sample 2 from Alawdin Fatima Zahra Masque.Other chloride value which recorded from groundwater of 
Darul Aman is $0.04 \mathrm{mg} / \mathrm{L}$ at Sample 3 from Animal Clinic another is $1.3 \mathrm{mg} / \mathrm{L}$ at sample 4 from Abas Qoli Salman Fars masque. The amount of chloride recommended by WHO and AFG National standard for is $250 \mathrm{mg} / \mathrm{L}$.

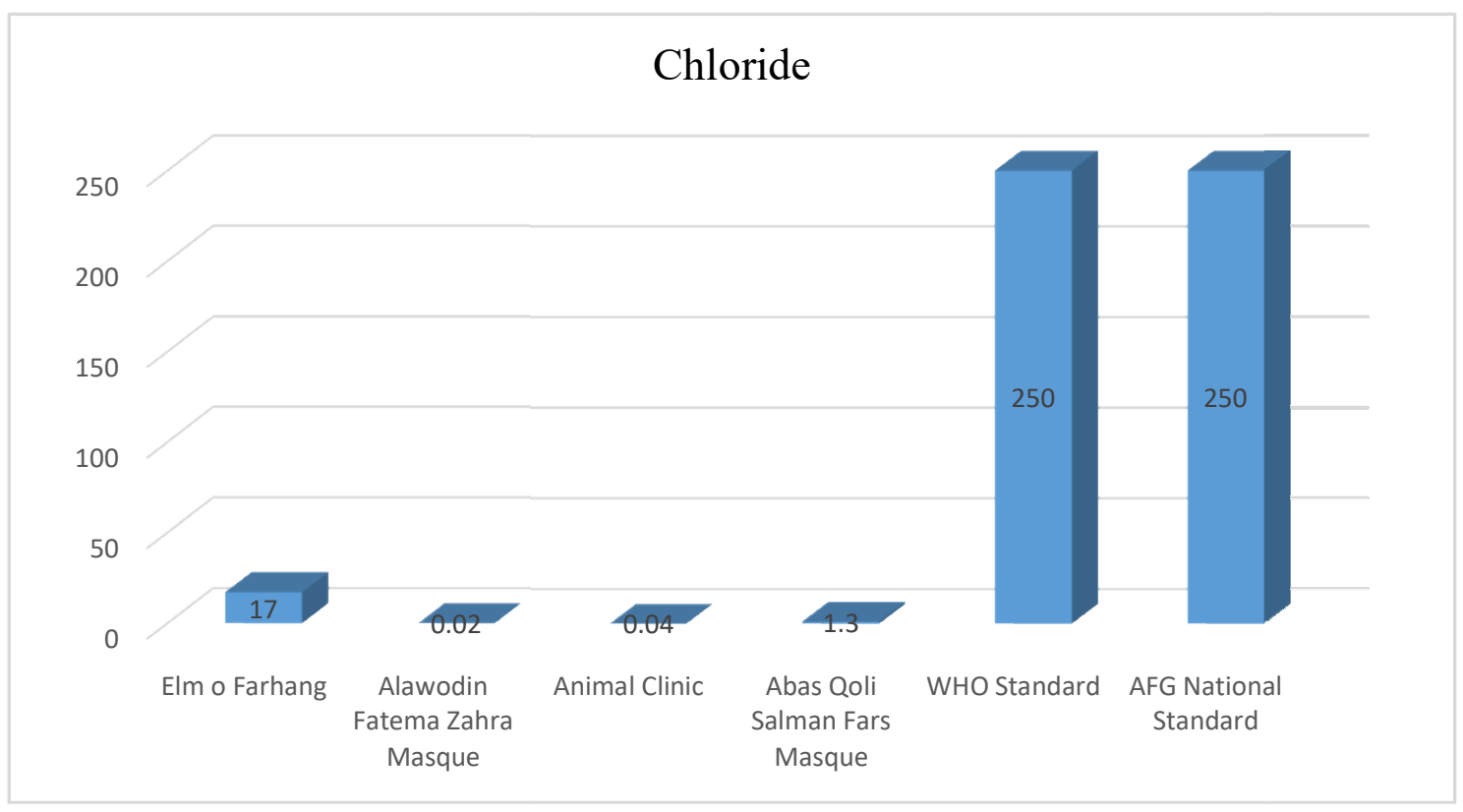

Figure 4: Chloride Compare

\section{5- Fluoride}

The amount of fluoride which recorded from groundwater of Darul Aman ranged from $0.22 \mathrm{mg} / \mathrm{L}$ to $0.41 \mathrm{mg} / \mathrm{L}$ with average of $0.29 \mathrm{mg} / \mathrm{L}$. The maximum fluoride value which recorded is $0.41 \mathrm{mg} / \mathrm{L}$ at Sample 1 from Elm o Farhang and minimum fluoride value which recorded is $0.22 \mathrm{mg} / \mathrm{L}$ at Sample 4 from Abas Qoli Salman Fars masque. Other fluoride value which recorded from groundwater of Darul Aman is $0.31 \mathrm{mg} / \mathrm{L}$ at Sample 3 from Animal Clinic another is $0.23 \mathrm{mg} / \mathrm{L}$ at sample 2 from Alawdin Fatima Zahra Masque. The amount of fluoride recommended by WHO and AFG National standard is $1.5 \mathrm{mg} / \mathrm{L}$. 


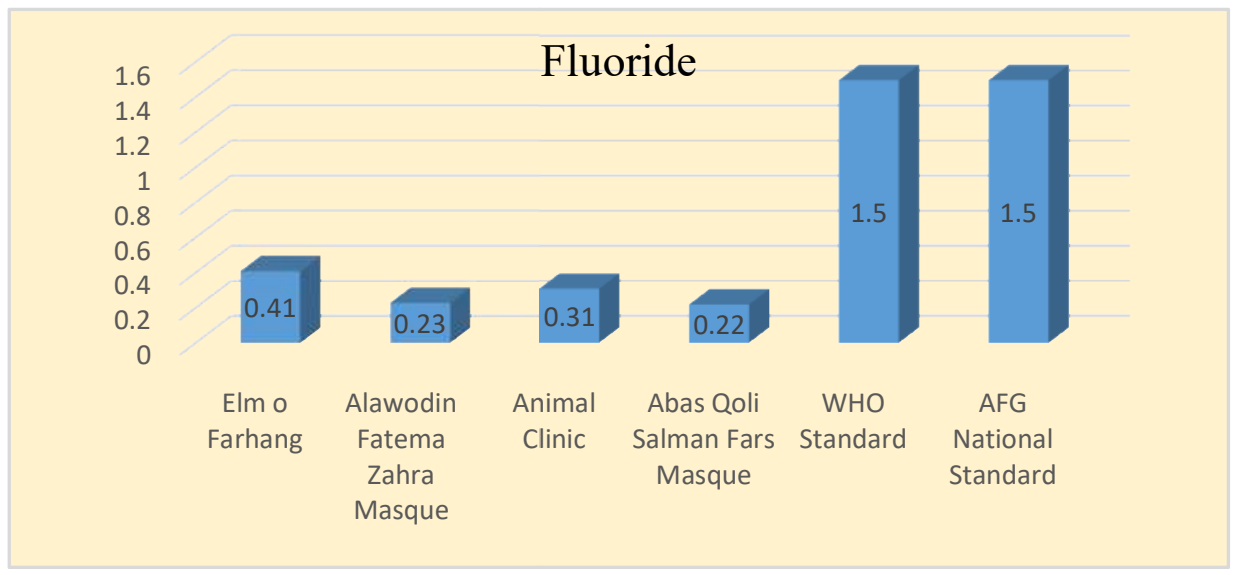

Figure 5: Fluoride Compare

\section{6- Phosphate}

The amount of phosphate which recorded from groundwater of Darul Aman ranged from $0.11 \mathrm{mg} / \mathrm{L}$ to $0.21 \mathrm{mg} / \mathrm{L}$ with average of $0.13 \mathrm{mg} / \mathrm{L}$. The maximum phosphate value which recorded is 0.21 $\mathrm{mg} / \mathrm{L}$ at Sample 1 from Elm o Farhang and minimum phosphate value which recorded is $0.11 \mathrm{mg} / \mathrm{L}$ at Sample 4 from Abas Qoli Salman Fars masque. Other phosphate value which recorded from groundwater of Darul Aman is $0.11 \mathrm{mg} / \mathrm{L}$ at Sample 4 from Animal Clinic another is $0.08 \mathrm{mg} / \mathrm{L}$ at sample 2 from Alawdin Fatima Zahra Masque. The amount of phosphate recommended by WHO is $0.1 \mathrm{mg} / \mathrm{L}$ and recommended value by AFG National standard for phosphate is not available.

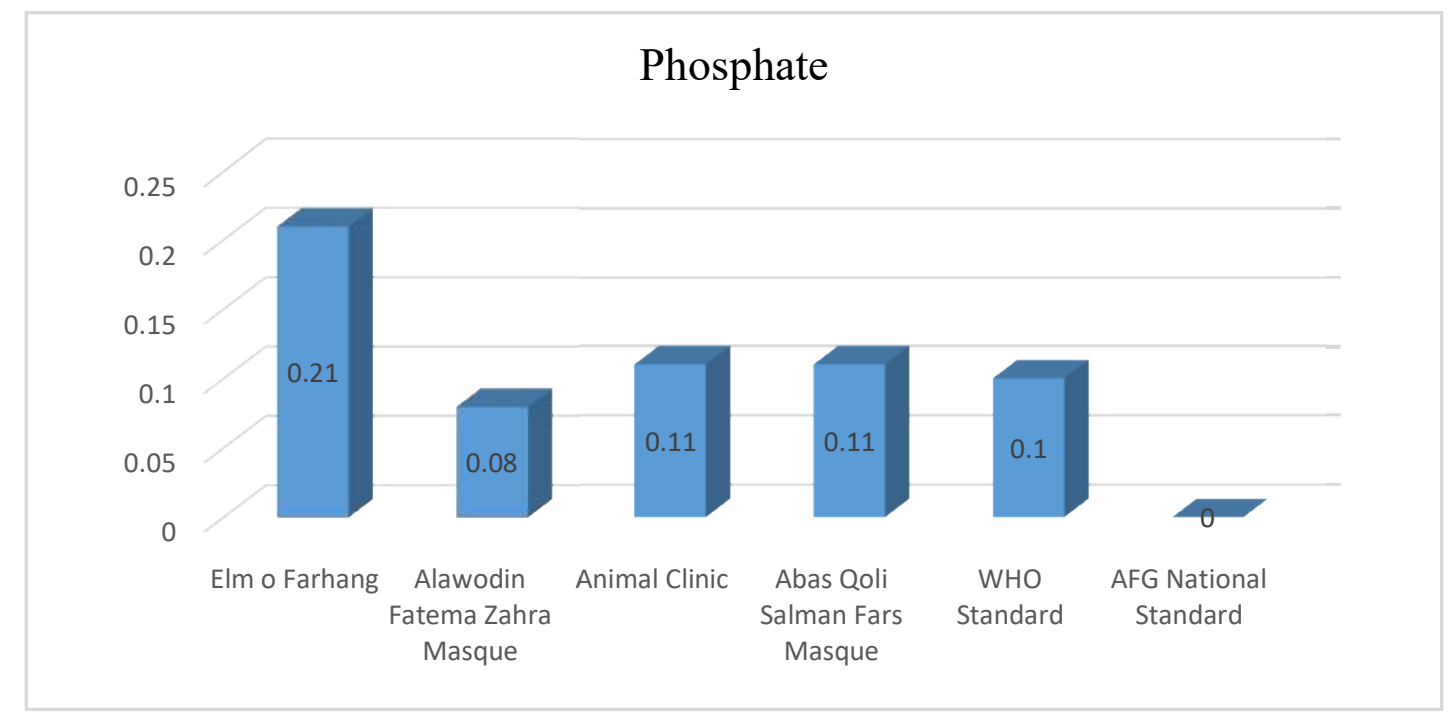

Figure 1: Phosphate Compare 
Towards Excellence: An Indexed, Refereed \& Peer Reviewed Journal of Higher Education / Abdul

Mohammad Aziz, Mohammad Dawod Shirzad, Dr. Hitesh Solanki / Page 734-751

\section{7- Nitrate}

The amount of nitrate which recorded from groundwater of Darul Aman ranged from $0.5 \mathrm{mg} / \mathrm{L}$ to 3.5 $\mathrm{mg} / \mathrm{L}$ with average of $1.92 \mathrm{mg} / \mathrm{L}$. The maximum nitrate value which recorded is $3.5 \mathrm{mg} / \mathrm{L}$ at Sample 1 from Elm o Farhang and minimum nitrate value which recorded is $0.5 \mathrm{mg} / \mathrm{L}$ at Sample 2 from Alawdin Fatima Zahra Masque. Other nitrate value which recorded from groundwater of Darul Aman is $2.3 \mathrm{mg} / \mathrm{L}$ at Sample 3 from Animal Clinic another is $1.4 \mathrm{mg} / \mathrm{L} \mathrm{mg} / \mathrm{L}$ at sample 4 from Abas Qoli Salman Fars masque. The amount of nitrate recommended by WHO and AFG National standard is 50 $\mathrm{mg} / \mathrm{L}$.

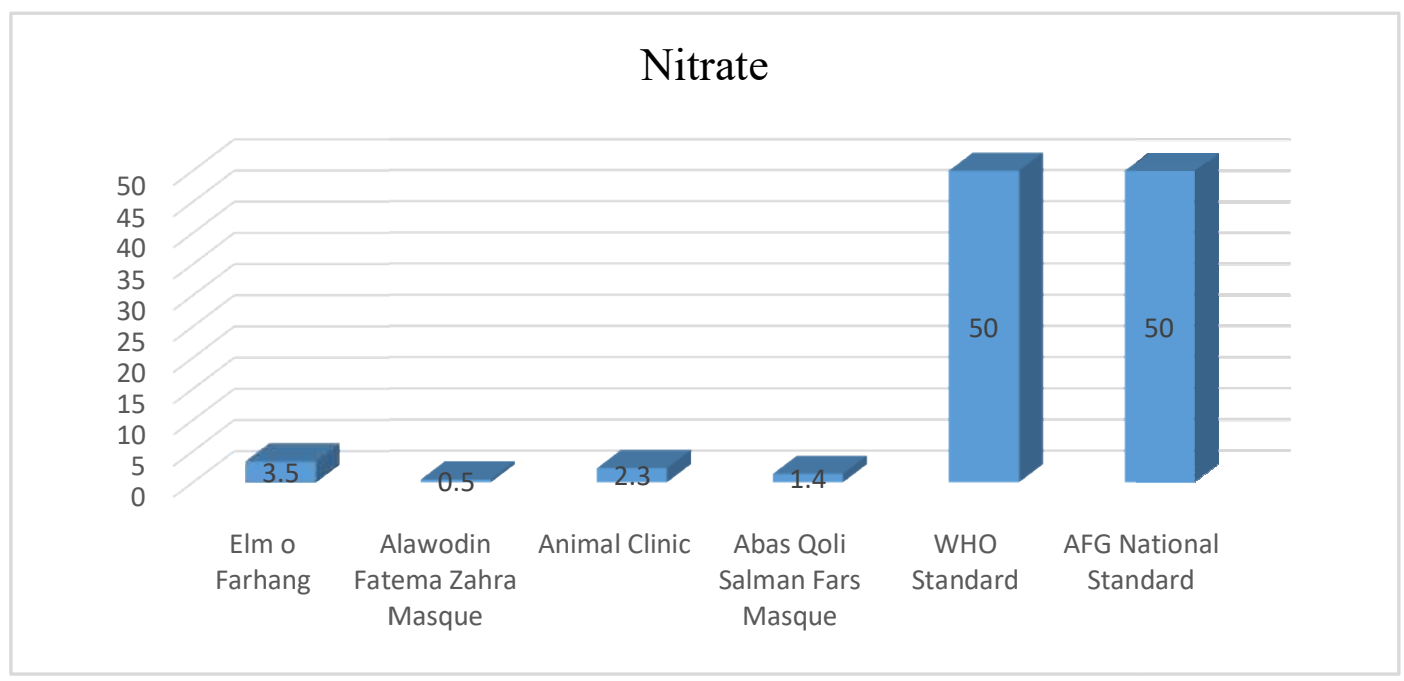

Figure 7: Nitrate Compare

\section{8- Cyanide}

The amount of cyanide which recorded from groundwater of Darul Aman ranged from $0.002 \mathrm{mg} / \mathrm{L}$ to $0.007 \mathrm{mg} / \mathrm{L}$ with average of $0 \mathrm{mg} / \mathrm{L}$. The maximum cyanide value which recorded is $0.007 \mathrm{mg} / \mathrm{L}$ at Sample 2 from Alawdin Fatima Zahra Masque and minimum cyanide value which recorded is 0.002 $\mathrm{mg} / \mathrm{L}$ at Sample 3 from Animal Clinic. Other cyanide value which recorded from groundwater of Darul Aman are $0.005 \mathrm{mg} / \mathrm{L}$ at Sample 1 and sample 4 from Elm o Farhang and Abas Qoli Salman Fars masque. The amount of cyanide recommended by WHO is $0.05 \mathrm{mg} / \mathrm{L}$ and recommended value by AFG National standard for cyanide is $0.07 \mathrm{mg} / \mathrm{L}$. 


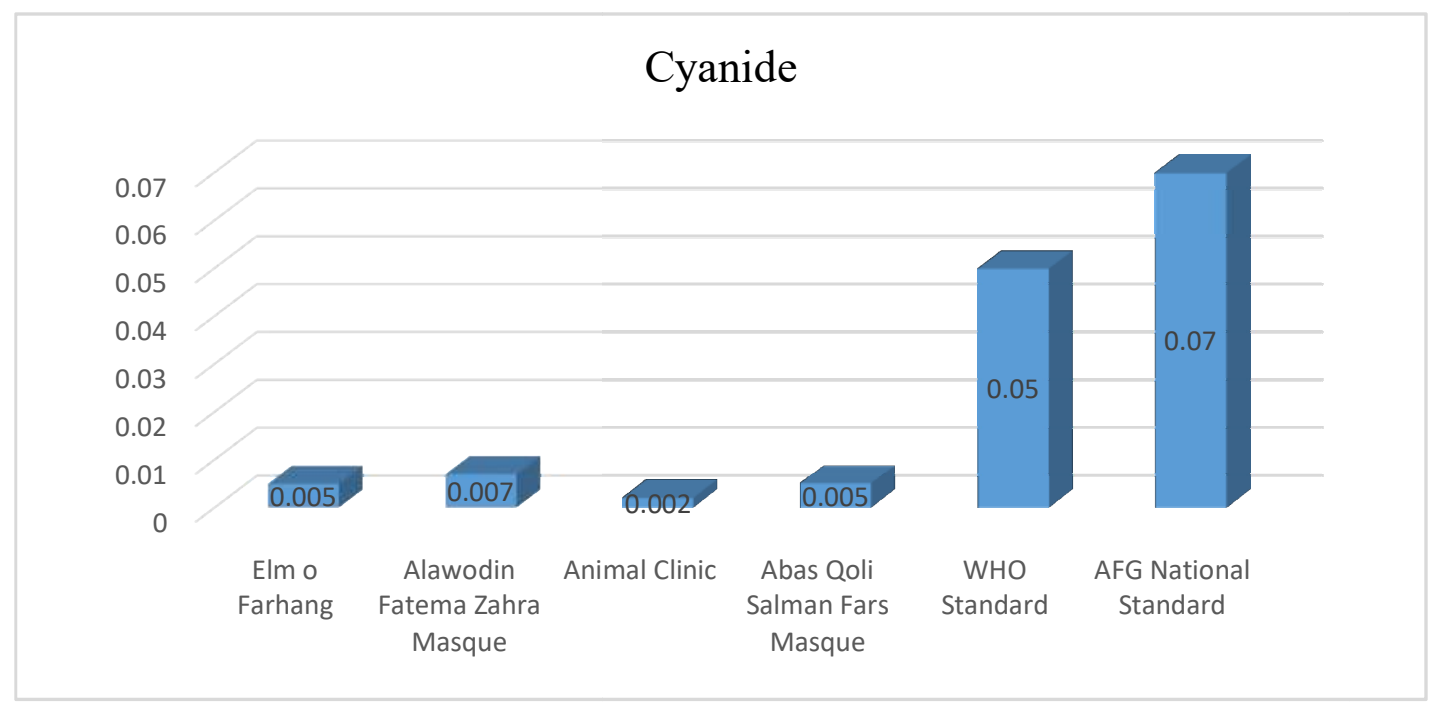

Figure 8: Cyanide Compare

Table 3: Result

\begin{tabular}{|l|l|l|l|l|l|l|l|}
\hline NO & Parameters & Unit & Min & Max & Mean & WHO & $\begin{array}{l}\text { AFG } \\
\text { Standard }\end{array}$ \\
\hline 1 & PH & - & 7.423 & 7.45 & 7.39 & $6.5-8.5$ & $6-9$ \\
\hline 2 & Magnesium & $\mathrm{mg} / \mathrm{L}$ & 40.2 & 90.14 & 69.17 & 30 & 30 \\
\hline 3 & Sodium & $\mathrm{mg} / \mathrm{L}$ & 84 & 270 & 208.5 & 200 & 200 \\
\hline 4 & Chloride & $\mathrm{mg} / \mathrm{L}$ & 0.02 & 17 & 4.59 & 250 & 250 \\
\hline 5 & Fluoride & $\mathrm{mg} / \mathrm{L}$ & 0.22 & 0.41 & 0.29 & 1.5 & 1.5 \\
\hline 6 & phosphate & $\mathrm{mg} / \mathrm{L}$ & 0.08 & 0.21 & 0.13 & - & 0.1 \\
\hline 7 & Nitrate & $\mathrm{mg} / \mathrm{L}$ & 0.5 & 3.5 & 1.92 & 50 & 50 \\
\hline 8 & Cyanide & $\mathrm{mg} / \mathrm{L}$ & 0.002 & 0.007 & 0 & 0.2 & \\
\hline
\end{tabular}

\section{CONCLUSIONS}

The analysis of groundwater samples collected from different points of Darul Aman revealed that, in samples almost all water quality parameters (PH, Calcium, Magnesium, Sodium, Chloride, Fluoride. Phosphate, Potassium Cyanide) are beyond the permissible limit as per WHO standards and Afghanistan national Standards. The conclusions of this research can be summarized as follows:

1. Most chemical parameters are almost below the maximum allowable level based on WHO and AFG National Standard. 
2. and lower concentrations of Chloride, Fluoride, Phosphate, Potassium, Cyanide In comparison to all other parameters there is an acute problem of extremely.

- Agriculture runoff.

- Effluent from septic systems or sewage discharges.

- Infiltration of domestic or wild animal fecal matter.

3. After evaluating the data of this study it is concluded that drinking water of Darul Aman is not potable and there is an instant need to take ameliorative steps in this region to prevent the population from adverse health effects.

\section{Recommendations}

1. Determine the source of your drinking water. If your water is supplied by a public water treatment plant, ask if they use surface water (streams, rivers, reservoirs) or groundwater as their source.

2. If you have a well, create a file with test results, maintenance history, depth, construction method and other information.

3. If you have a septic system, make sure it is inspected and your tank is pumped on a regular basis.

4. Do not use septic tank additives, and do not pour harmful chemicals down any drain in your house.

5. Never pour motor oil or any other pollutant on the ground.

6. It is also recommended to use water only after boiling and filtering or by Reverse Osmosis

7. treatment for drinking purpose by the individuals to prevent adverse health effects. 
Towards Excellence: An Indexed, Refereed \& Peer Reviewed Journal of Higher Education / Abdul

Mohammad Aziz, Mohammad Dawod Shirzad, Dr. Hitesh Solanki / Page 734-751

\section{References}

1- Çevik, F., Derici, O., Gürbüz, G., \&Güzel, E. (2016). Assessment of Physico-Chemical Parameters of Water of Çatalan Dam Lake, Turkey. Asian Journal of Chemistry, 28(9), 20982102. doi: 10.14233/ajchem.2016.20041.

2- Gupta, N., Pandey, P., \& Hussain, J. (2017). Effect of physicochemical and biological parameters on the quality of river water of Narmada, Madhya Pradesh, India. TITLE=Water Science, 31(1), 11-23. https://doi.org/10.1016/j.wsj.2017.03.002

3- Dirican, S., Gupta, N., Pandey, P., Hussain, J., Khan, M. A., Yousafzai, A. M., Chaudhari, K. G. (2015). Assessment of Water Quality Using Physico-chemical Parameters of Camligoze Dam Lake in Sivas, Turkey. International Journal of Current Microbiology and Applied Sciences, 3(1), 1-5 https://doi.org/10.1080/23311916.2016.1237927.

4- Ramteke, S., Verma, V., Chakradhari, S., Sahu, P. K., Sahu, B. L., Rajhans, K. P., ... Patel, K. S. (2016). Pit Lake Water Quality of Central India. Journal of Geographic Information System, 08(01), 28-39. https://doi.org/10.4236/jgis.2016.81003.

5- Maurya RR, Q. U. (2015). Determination of Physico-Chemical Parameters and Water Quality Index (Wqi) of Chandlodia Lake, Ahmedabad, Gujarat, India. Journal of Environmental \& Analytical Toxicology, 05(04). https://doi.org/10.4172/2161-0525.1000288.

6- Khan, M. A., Yousafzai, A. M., Afshan, N., ul Akbar, N., Raza, M. K., Hussain, H., \& Mumtaz, T. (2015). Physicochemical Parameters of water Collected from River Panjkora, Khyber Physicochemical Parameters of water Collected from. (January). https ://doi.org/10.5829/idosi.wjfms.2015.7.6.96196.

7- Dwivedi SL, Patha V (2007) A preliminary assignment of water quality index to Mandakini river, Chitrakoot. Indian J Environ Protect 27:1036-1038.

8- Iyer, V., Choudhury, N., Azhar, G. S., \& Somvanshi, B. (2014). Drinking Water Quality Surveillance in a Vulnerable Urban Ward of Ahmedabad. (May), 1165-1171. Joshi, D. M., Kumar, A., \& Agrawal, N. (2009). STUDIES ON.

9- Raphy Favre, Watershed Consultant (2004) Watershed atlas of Afghanistan, (1sted.). Working Document For Planers, Ministry of Irrigation, Water Resources and Environment of Afghanistan.

10-Shah, T., Singh, O. P., \& Mukherji, A. (2006) Some aspects of South Asia's groundwater irrigation economy: analyses from a survey in India, Pakistan, Nepal Terai and Bangladesh. Hydrogeology Journal 14:286-309 .

11-NESCO Institute for Statistics. http://data.uis.unesco.org/

12- Japan International Cooperation Agency (JICA) Study Team, 2011. Draft Kabul City Master March, 2021. VOL.13. ISSUE NO. $1 \quad$ https://hrdc.gujaratuniversity.ac.in/Publication $\quad$ Page | 749 
Towards Excellence: An Indexed, Refereed \& Peer Reviewed Journal of Higher Education / Abdul Mohammad Aziz, Mohammad Dawod Shirzad, Dr. Hitesh Solanki / Page 734-751

Plan. Product of Technical Cooperation Project for Promotion of Kabul Metropolitan Area Development Sub Project for Revise the Kabul City Master Plan.

13-Eqrar, N., 2015. Groundwater Quantity and Quality problems in Kabul cityUniversity of Kabul.

14-Saffi, M. Hassan, 2011. Groundwater natural resources and quality concerns in Kabul Basin, Afghanistan - DACAAR Kabul.

15-Ait-Kadi, M., 2016. Water for Development and Development for Water: Realizing the Sustainable Development Goals (SDGs) Vision, Aquatic Procedia Vol. 6, pp. $106-110$.

16- World Health Organization (WHO), 2015. Drinking Water. Fact sheet no. 391.

17-Bain, R., Cronk, R., Wright, J., Yang, H., Slaymaker, T., and Bartram, J., 2014. Fecal contamination of drinking-water in low-and middle-income countries: a systematic review and meta-analysis. PLoS medicine, Vol. 11, No 5.

18-Lu, W., Xie, Sh., Zhou, W., Zhang, Sh. and Liu, A., 2008. Water Pollution and Health Impact in China: A Mini Review. Open Environmental Sciences Vol. 2. pp. 1-5.

19-Houben, G., Tünnermeier, T., Eqrar, N. and Himmelsbach, T., 2009. Hydrogeology of the Kabul Basin (Afghanistan), part II: Groundwater geochemistry. Hydrogeology Journal Vol. 17, pp. 935-948.

20-Mubarak, M. Y., 2012. Drinking water safety and sanitation in relation to diarrheal diseases in under-developed areas of District 5, Kabul, Afghanistan, pp.2 - 15.

21-Saffi, M. H., 2013. Scientific Investigation Report in Afghanistan Water Resources Potential, Quality Problems, Challenges and Solutions in Afghanistan, Kabul, Scientific Investigation Report July 2013.

22-Mack, T. J., Chornack, M. P., Coplen, T. B., Plummer, L.N., Rezai, M. T., and Verstraeten, I. M., 2010. Availability of Water in the Kabul Basin, Afghanistan. No. 2010-3037. US Geological Survey.

23-WHO/UNICEF ,2012. Progress on drinking water and Sanitation, joint Monitoring Program.

24-Kakar, F., Ahmadzai, A. H., Habib, N., Taqdeer, A. and Hartman, A, F., 2008. A successful response to an outbreak of cholera in Afghanistan Tropical doctor Short Report July 2008.

25-Mumtaz, A., 2008. Assessment and Mitigation of Water - Related Environmental Health Impacts in the Bagrami District of Kabul Province. A thesis presented for the degree of Master of Science (MSc), University of Montana Missoula, MT.

26- Eqrar, M. N., 2008. Water supply and sanitation of Kabul basin, Coupling sustainable sanitation and groundwater protection Symposium, Hannover.

27- Solanki Hiteshkumar 2012. Status of Soils and Water Reservoirs near Industrial areas of

March, 2021. VOL.13. ISSUE NO. $1 \quad$ https://hrdc.gujaratuniversity.ac.in/Publication $\quad$ Page | 750 
Towards Excellence: An Indexed, Refereed \& Peer Reviewed Journal of Higher Education / Abdul Mohammad Aziz, Mohammad Dawod Shirzad, Dr. Hitesh Solanki / Page 734-751

Baroda: Pollution and Soil- Water Chemistry. Lamberd Academic Publishing, Germany.

Abdul Mohammad Aziz

Faculty of Chemistry, Kabul University, Kabul, Afghanistan

\&

Mohammad Dawod Shirzad

Faculty of Environment, Kabul University, Kabul, Afghanistan

mshirzad.ku@gmail.com

\&

Prof. Dr. Hitesh Solanki

Head, Department of Environmental Science, Gujarat University, Ahmedabad

hasolanki@gujaratuniversity.ac.in

Phone: +93794768541 